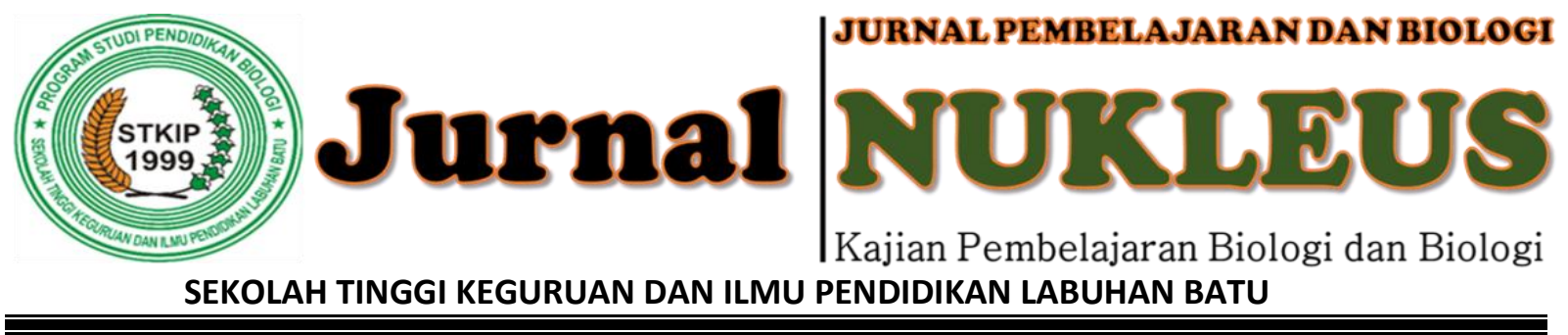

\title{
STUDI KEANEKARAGAMAN PLANKTON SEBAGAI PAKAN ALAMI UDANG PADA PERAIRAN EKOSISTEM MANGROVE BELAWAN, SUMATERA UTARA
}

\author{
RIVO HASPER DIMENTA ${ }^{(1)}, \operatorname{KHAIRUL}^{(1)}, \operatorname{RUSDI}_{\text {MACHRIZAL }}^{(1)}$ \\ (1) Pendidikan Biologi, STKIP Labuhan Batu \\ Jalan SM Raja No 126 A, Aek Tapa, Rantauprapat *email: rivohd11@gmail.com
}

\section{Info Artikel}

Riwayat Artikel:

Diterima Juni 2018

Disetujui Agustus 2018

Dipublikasikan Agustus

2018

\begin{abstract}
Abstrak
Penelitian ini bertujuan untuk mengetahui keanekaragaman plankton yang menjadi pakan alami dari udang kelong ( $P$. indicus). Penelitian telah dilakukan selama 2 bulan di sekitar perairan muara sungai yang memiliki ekosistem mangrove Belawan, pada bulan Mei hingga Juni 2017. Metode yang digunakan dalam penentuan lokasi sampling untuk pengambilan sampel plankton adalah "Purposive Sampling" pada 5 (lima) stasiun pengamatan dengan 2 kategori zona yaitu zona alami dan zona pemanfaatan, dilakukan 3 (tiga) kali ulangan setiap stasiun. sampel plankton diambil dengan menggunakan Plankton Net. Analisa data Kelimpahan Plankton menggunakan persamaan (APHA, 1998), untuk indeks keanekaragaman Plankton dengan persamaan Indeks Shannon-Wiener $\left(\mathrm{H}^{\prime}\right)$, dan Analisa Korelasi Kelimpahan Terhadap Parameter Biologi (udang dan mangrove) menggunakan analisis korelasi Pearson dari perangkat lunak SPSS versi 20. Hasil penelitian diperoleh Kelimpahan plankton tertinggi dijumpai pada stasiun 1 dan 3 yang didominasi oleh kelompok fitoplankton dari genus Melosira, Gonatozygon, Skeletonema, Asterionellopsis, Ceratium, Thalassionema, Odontella, Nitzchia, dan Coscinodiscus, serta Kelompok zooplankton dari genus Brachionus dan Cyclops. Sedangkan Kelimpahan plankton terendah dijumpai pada stasiun 2 dan 5 . Nilai indeks keanekaragaman $\left(\mathrm{H}^{\prime}\right)$ plankton tertinggi ditemukan pada stasiun $1(2,26)$ yang merupakan kawasan alami dengan minim aktivitas manusia dan memiliki ragam jenis mangrove, serta merupakan area pasang-surut yang baik. Sedangkan nilai indeks keanekaragaman $\left(\mathrm{H}^{\prime}\right)$ plankton terendah pada stasiun $2(0,97)$ yang berlokasi paling jauh dari muara sungai Belawan. Hasil analisis korelasi pearson antara kelimpahan plankton terhadap faktor biologi lingkungan (kerapatan mangrove dan populasi udang kelong $P$. indicus) menunjukkan korelasi positif/searah yang sangat kuat dengan nilai masing-masing sebesar 0.91 dan 0.94
\end{abstract}

Kata Kunci: Penaeus indicus, Plankton, Pakan Alami, Sicanang-Belawan

\section{PENDAHULUAN}

Salah satu sumberdaya hayati yang mempunyai peranan penting dalam ekosistem laut adalah plankton. Plankton merupakan organisme yang hidup melayang-layang di air dan mempunyai kemampuan berenang yang lemah. Faiqoh (2009) plankton dibagi menjadi dua golongan besar yaitu fitoplankton dan zooplankton. Masing-masing mempunyai peranan yang penting bagi ekosistem perairan.

Zooplankton merupakan biota yang berperan penting terhadap produktivitas sekunder dan konsumen pertama dalam wilayah perairan (Melay dan Rahalus, 2014). Selain itu, keberadaan zooplankton pada suatu perairan dapat digunakan untuk mengetahui tingkat produktivitas suatu perairan. Oleh karenanya perubahan yang terjadi pada suatu wilayah perairan dapat diketahui dengan melihat perubahan kelimpahan biota zooplankton. Sedangkan Fitoplankton umumnya dominan ditemukan di sekitar muara sungai, seperti pada muara Belawan yang memiliki ekosistem mangrove. Hal ini terjadi karena Arinardi et al. (1996) masuknya zat hara dari daratan yang masuk ke sungai dan dialirkan ke laut melalui proses pasang-surut air.

Muara Belawan merupakan salah satu area estuari/pesisir pantai timur Sumatera yang memiliki ekosistem dengan potensi mangrove menurut Dinas Kehutanan Sumatera Utara (2011) luasnya saat ini sebesar 158.637,2 hektar. Secara administratif, ekosistem ini berada diantara 2 kecamatan yaitu kecamatan Medan Belawan (Kota Madya Medan) dan kecamatan Hamparan Perak. Tingginya kegiatan konversi lahan tersebut dengan nilai persentase degradasi lahan menurut Dinas Kehutanan Sumatera Utara (2011) di Medan 
Belawan dan Hamparan Perak masing-masing sebesar $76,42 \%$ dan $76,47 \%$ dari luas mangrove. Kondisi tersebut diduga mempengaruhi ketersediaan dan keanekaragaman plankton yang merupakan pakan alami udang. Fajrina et al (2013) Perubahan kelimpahan maupun jumlah jenis plankton dapat digunakan sebagai indikator kesuburan perairan pada wilayah tersebut, dan memberikan dampak dari perubahan kondisi lingkungan. Berdasarkan analisa tersebut, dipandang perlu dilakukan penelitian untuk mengetahui komposisi keanekaragaman plankton dan serta untuk mengetahui korelasinya terhadap parameter biologi berupa populasi udang dan mangrove yang berada di sekitar perairan mangrove, muara sungai Belawan.

\section{METODE PENELITIAN}

\section{Waktu dan Tempat}

Pengambilan sampel air dilakukan selama 2 bulan pada bulan Mei hingga Juni 2017 di sekitar perairan ekosistem mangrove muara Belawan. Metode yang digunakan dalam penentuan lokasi sampling untuk pengambilan sampel plankton adalah "Purposive Sampling" pada 5 (lima) stasiun pengamatan. Pada masing-masing stasiun dilakukan 3 (tiga) kali ulangan.

\section{Deskripsi Area}

a. Stasiun 1 terletak pada titik ordinat 0345'52.7" LU dan 98 $38^{\circ}$ '53.4" BT yang berada yang merupakan kawasan zona alami yang minim aktivitas masyarakat,

b. Stasiun 2 terletak pada titik ordinat 0344'58.0" LU dan 98³8'50.6" BT yang berdekatan dengan pemukiman penduduk,

c. Stasiun 3 terletak pada titik ordinat 0346'09.5" LU dan 98 ' $^{\circ} 8^{\prime} 01.8^{\prime \prime}$ BT yang berada berdekatan dengan kawasan wisata,

d. Stasiun 4 terletak pada titik ordinat 034'54.2" LU dan 98०37'32.6" BT yang berada di kawasan perkebunan kelapa sawit,

e. Stasiun 5 terletak pada titik ordinat 034'17.2" LU dan 98 ${ }^{\circ} 37^{\prime} 47.2^{\prime \prime}$ BT yang berada di kawasan pertambakan.

\section{Alat dan Bahan}

Adapun alat yang digunakan dalam penelitian ini adalah ember kapasitas 5 liter, plankton net, botol sampel, pipet tetes, cool box, object glass, alat tulis, GPS (Global Positioning System), kamera digital, botol winkler, mikroskop, Sedgwick Rafter, refraktometer, termometer, $\mathrm{pH}$ meter, sechi disk. Bahan yang digunakan adalah larutan Lugol $10 \%$, $\mathrm{KOH}-\mathrm{KI}, \mathrm{MnSO}_{4}, \mathrm{H}_{2} \mathrm{SO}_{4}$, Amilum $10 \%$, dan $\mathrm{Na}_{2} \mathrm{~S}_{2} \mathrm{O}_{3}$ dan kertas label.

\section{Prosedur Penelitian}

\section{Pengambilan sampel Plankton}

Sampel plankton diambil dengan cara menyaring air lapisan permukaan dengan kedalaman 30-40 cm sebanyak 25 liter dengan menggunakan ember volume 5 liter. Sampel tersebut disaring menggunakan plankton net dengan ukuran $45 \mu \mathrm{m}$, air sampel hasil penyaringan yang tertampung di bucket dimasukan ke dalam botol sampel volume $30 \mathrm{ml}$ dan diawetkan dengan menggunakan Lugol sebanyak 4 tetes. Selanjutnya, sampel plankton disimpan di dalam box dan dibawa ke laboratorium untuk diidentifikasi.

\section{Pengukuran Parameter Lingkungan (Fisika- Kimia Perairan)}

Parameter fisika-kimia dianalisis secara Insitu dan Exsitu, detail pengukuran dapat dilihat pada tabel 1

\section{Analisa Data}

Kelimpahan Plankton (APHA, 1998)

$\begin{aligned} \mathrm{N} & =\mathrm{T} / \mathrm{L} \times \mathrm{P} / \mathrm{p} \times \mathrm{V} / \mathrm{v} \times 1 / \mathrm{w} \\ \text { Keterangan: } & \\ \mathrm{N} & =\text { Jumlah plankton per liter } \\ \mathrm{T} & =\text { Luas Sedwick-rafter } \\ \mathrm{L} & =\text { Luas lapangan pandang } \\ \mathrm{P} & =\text { Jumlah plankton yang tercacah } \\ \mathrm{p} & =\text { Jumlah lapangan pandang yang } \\ \mathrm{V} & =\text { diamati } \\ \mathrm{V} & =\text { Volume sampel air yang tersaring } \\ \mathrm{w} & =\text { Volume sampel plankton pada } \\ \mathrm{w} & \text { Volas penutup }(\mathrm{ml}) \\ & \end{aligned}$

Tabel 1. Parameter yang diukur, satuan, alat/bahan/metode yang digunakan, dan tempat pengukuran

\begin{tabular}{|c|c|c|c|c|}
\hline Parameter & & Satuan & $\begin{array}{c}\text { Alat/bahan \& metode } \\
\text { yang digunakan }\end{array}$ & $\begin{array}{c}\text { Tempat } \\
\text { Pengukuran }\end{array}$ \\
\hline Suhu Air & & ${ }^{\circ} \mathrm{C}$ & Termometer $\mathrm{Hg}$ & In-situ \\
\hline Salinitas Air & & $\%$ & Hand Refraktometer & In-situ \\
\hline Kecerahan & & $\mathrm{Cm}$ & Keping Sechi & In-situ \\
\hline DO (Oksigen Terlarut) & & $\mathrm{mg} / \mathrm{l}$ & Titrasi Winkler & In-situ \\
\hline $\mathrm{BOD}_{5}$ & & $\mathrm{mg} / \mathrm{l}$ & Titrasi Winkler & Laboratorium \\
\hline $\begin{array}{l}\text { Kandungan Total Suspended } \\
\text { (TSS) }\end{array}$ & Solid & $\mathrm{mg} / \mathrm{l}$ & Gravimetri & Laboratorium \\
\hline Kandungan $\mathrm{NO}_{3} \& \mathrm{PO}_{4}$ & & $\mathrm{mg} / \mathrm{l}$ & Spektrofometer & Laboratorium \\
\hline Kerapatan Mangrove & & Ind/Ha & Metode Kuadrat & In-situ \\
\hline $\begin{array}{l}\text { Kelimpahan } \\
\text { (P.indicus) }\end{array}$ & Udang & Ind $/ M^{2}$ & Jaring Udang & In-situ \\
\hline
\end{tabular}

\section{Indeks Keanekaragaman Plankton $\left(\mathbf{H}^{\prime}\right)$}

Penghitungan indeks keanekaragaman plankton dilakukan dengan menggunakan Indeks Shannon-Wiener ( $\left.\mathrm{H}^{\prime}\right)$ Fachrul (2007),

$$
\mathrm{H}^{\prime}=\sum_{i=1}^{s} \mathrm{Pi} \ln \mathrm{Pi} \text { dengan } \mathrm{Pi}=\mathrm{ni} / \mathrm{N}
$$

Keterangan: 
$\mathrm{H}^{\prime}=$ Indeks keanekaragaman jenis

$\mathrm{pi}=\mathrm{ni} / \mathrm{N}$

$\mathrm{Ni}=$ Jumlah individu jenis ke-i

$\mathrm{N}$ = Jumlah total individu

Dimana jika;

$\mathrm{H}^{\prime}<1=$ Keanekaragaman rendah

$1<\mathrm{H}^{\prime}<3=$ Keanekaragaman sedang

$\mathrm{H}^{\prime}>3=$ Keanekaragaman rendah

\section{Analisa Korelasi Kelimpahan Terhadap Parameter Biologi (Populasi Udang Kelong (Penaeus indicus) dan Kerapatan Mangrove) Lingkungan}

Uji statistik yang dilakukan untuk mengetahui hubungan antara plankton dengan data udang kelong yang tertangkap menggunakan analisis korelasi Pearson dengan perangkat komputerisasi SPSS versi 20.

\section{HASIL PENELITIAN}

\section{Kelimpahan Plankton}

Dari penelitian yang telah dilakukan diperoleh 36 jenis plankton yang terbagi atas 31 jenis fitoplankton yang terbagi atas 8 kelas yaitu: Bacillariophyceae, Chlorophyceae, Conjugatophyceae, Coscinodiscophyceae, Cyanophyceae, Dinophyceae, Euglenophyceae, dan Fragillariophyceae. Untuk zooplankton diperoleh 5 jenis, terbagi atas 3 kelas yaitu: Brachiopoda, Maxillopoda, Monogononta (Tabel 2). Nilai kelimpahan tertinggi dijumpai pada stasiun 1 dan 3 yang didominasi oleh kelompok fitoplankton dengan genus Melosira, Gonatozygon, Skeletonema, Asterionellopsis, Ceratium, Thalassionema, Odontella, Nitzchia, dan Coscinodiscus. Kelompok zooplankton dengan genus Brachionus dan Cyclops. Nilai kelimpahan plankton terendah dijumpai pada stasiun 2 dan 5.

Dominasi kehadiran genus fitoplankton kemungkinan disebabkan oleh pengambilan sampel yang dilakukan pada siang hari dan pada saat peralihan musim hujan menuju kemarau (pada bulan Mei - Juni) sehingga suhu mulai meningkat, sedangkan zooplankton merupakan hewan nokturnal yang kurang menyukai intensitas cahaya berlebihan. Menurut Davis (1955) faktor perangsang migrasi vertikal harian pada zooplankton adalah cahaya. Peningkatan intensitas cahaya akan mengakibatkan zooplankton bergerak menjauhi permukaan dan mempertahankan posisinya pada kedalaman dengan intensitas cahaya tertentu.

Saat siang hari atau intensitas cahaya matahari maksimal, zooplankton berada pada kedalaman paling jauh. Hal ini disebabkan oleh perilaku zooplankton dalam menghindari pemangsaan yang mendeteksi mangsa secara visual, mengubah posisi di dalam perairan dan mekanisme dalam meningkatkan produksi dan menghemat energi. Supriadi (2001) menambahkan pada wilayah estuari tropik, air pada permukaan maupun di dasar cukup menerima cahaya matahari sepanjang tahun sehingga kondisi cahaya tetap optimal bagi produksi fitoplankton. Perairan yang memiliki nilai fosfat rendah, akan didominasi oleh fitoplankton jenis diatom, dibandingkan dengan fitoplankton jenis lain.

Kehadiran plankton akan sangat mendukung kehidupan udang di alam, karena baik fitoplankton dan zooplankton merupakan pakan alami yang tersedia di perairan estuari yang memiliki kandungan salinitas beragam, sehingga memungkinkan bagi kehidupan beranekaragam plankton. Menurut Sumeru \& Anna (1992); Fast \& Lester (1992), udang penaeid merupakan hewan omnivora dan predator bagi invertebrata yang pergerakannya lambat. Biasanya mengkonsumsi berbagai jenis bracyura, fitoplankton, polychaeta, moluska, ikan-ikan kecil dan crustaceae kecil dalam jumlah yang terbatas. Menurut Angsupanich et al., (1999) kandungan isi lambung udang $P$. indicus berisi $42 \%$ Bilvalvia, $9.8 \%$ gastropoda, $35.1 \%$ Amphipoda, $0.1 \%$ Brachyura, $0.5 \%$ Copepoda, $0.6 \%$ Isopoda, $4.9 \%$ Foraminifera, 10 $\%$ Bacillariophyceae, dan $4 \%$ potongan jaringan tumbuhan.

Tabel 2. Kelimpahan (ind/L) Plankton pada Seluruh Stasiun Pengamatan

\begin{tabular}{lrrrrr}
\hline \multicolumn{1}{c}{ Genus } & \multicolumn{5}{c}{ Stasiun Pengamatan } \\
\cline { 2 - 5 } & $\mathbf{1}$ & $\mathbf{2}$ & $\mathbf{3}$ & $\mathbf{4}$ & $\mathbf{5}$ \\
\hline Fitoplankton & & & & & \\
1. Asterionellopsis & 4592 & 1653 & 5143 & 1469 & 918 \\
2. Bacteriastrum & 2020 & 367 & 4163 & 0 & 0 \\
3. Biddulphia & 0 & 735 & 0 & 551 & 551 \\
4. Cerataulina & 735 & 551 & 1469 & 367 & 0 \\
5. Ceratium & 3857 & 4408 & 5510 & 3306 & 4592 \\
6. Chaetoceros & 1102 & 0 & 918 & 551 & 367 \\
7. Chlorococcum & 551 & 0 & 1286 & 367 & 918 \\
8. Closteriopsis & 551 & 0 & 245 & 918 & 0 \\
9. Closterium & 1653 & 735 & 367 & 0 & 367 \\
10. Coscinodiscus & 3122 & 2571 & 4224 & 3306 & 3857 \\
11. Diatoma & 0 & 1469 & 1102 & 1653 & 735 \\
12. Dinophysis & 2939 & 1653 & 2204 & 1469 & 367 \\
13. Ditylum & 2571 & 1102 & 1837 & 735 & 367 \\
14. Euglena & 1286 & 0 & 735 & 0 & 0 \\
15. Fragillaria & 735 & 918 & 551 & 184 & 184 \\
16. Gonatozygon & 5694 & 3857 & 4408 & 2939 & 4776 \\
17. Lauderia & 4592 & 0 & 3122 & 2388 & 0 \\
18. Melosira & 7224 & 5816 & 5939 & 5020 & 5449 \\
19. Navicula & 1653 & 735 & 735 & 735 & 918 \\
20. Nitzchia & 3122 & 1102 & 1286 & 551 & 367 \\
21. Odontella & 3490 & 1653 & 2510 & 1469 & 1286
\end{tabular}




\begin{tabular}{lrrrrr} 
22. Oscillatoria & 918 & 1469 & 551 & 2020 & 3857 \\
23. Protoperidinium & 3306 & 0 & 2755 & 367 & 0 \\
24. Rhizosolenia & 1102 & 0 & 1653 & 735 & 0 \\
25. Skeletonema & 5694 & 7041 & 4898 & 8143 & 5204 \\
26. Tabellaria & 1102 & 0 & 673 & 918 & 735 \\
27. Thalasionema & 4776 & 3490 & 3245 & 4224 & 4592 \\
28. Thalassiosira & 0 & 735 & 918 & 367 & 1286 \\
29. Thalassiothrix & 2388 & 918 & 551 & 1286 & 1286 \\
30. Ulothrix & 0 & 0 & 551 & 1102 & 1653 \\
31. Volvox & 367 & 551 & 1653 & 735 & 551 \\
\hline Zooplankton & \multicolumn{7}{c}{ Tosmina } & 0 & 0 & 735 & 367 & 367 \\
\hline 32. Bosmina & 3000 & 1469 & 3306 & 1837 & 2204 \\
33. Brachionus & 1469 & 735 & 2204 & 1837 & 1102 \\
34. Cyclops & 1469 & 367 & 918 & 0 & 551 \\
35. Diacyclops & 367 & 0 & 918 & 367 & 551 \\
36. Diaptomus & 77449 & 48857 & 73286 & 52286 & 49959 \\
\hline \multicolumn{1}{c}{ Total } & & & & &
\end{tabular}

Sumeru \& Anna (1992) menjelaskan bahwa kandungan isi lambung udang windu yang dipelihara di tambak menunjukkan makanan yang dikonsumsi terdiri dari fitoplankton jenis Lyngbya sp., Spirulina sp., Skeletonema sp. dan zooplankton jenis Brachionus sp. Walaupun demikian, keadaan/ketersediaan pakan yang terdapat pada habitat udang tersebut akan mempengaruhi jenis makanan yang dikonsumsinya.

Menurut Edhy et al., (2010); Liao \& Murai (1986) Larva udang penaeid membutuhkan pakan untuk pertumbuhannya. Pada saat telur udang menetas menjadi nauplius, kebutuhan nutrisi larva udang diperoleh dari cadangan makanan pada kuning telur yang dibawa sejak menetas. Pada stadia zoea, udang mulai memakan fitoplankton berupa diatom (Skeletonema, Chaetoceros, Navicula, Chlorella, Coscinodiscus, Amphora, dan lainnya) serta Dinoflagellata (Tetraselmis, dan lainnya), detritus dan nauplius udang-udang kecil. Sejalan dengan perkembangan udang pada stadia mysis, anggota tubuhnya seperti ekor kipas, kaki jalan, dan ruas-ruas kaki renang akan meningkatkan kemampuannya untuk mengejar mangsa-mangsa bergerak sehingga udang mulai mengkonsumsi makanan berupa zooplankton, Protozoa, Rotifera (Branchionus), anak tritip (Balanus), anak kutu air (Copepoda).
Selain makanan yang diperoleh dari permukaan air udang pada stadium post larva, dan udang muda (juvenil) juga mengkonsumsi organisme yang terdapat di dasar perairan berupa bentos, anak tiram, anak tritip, anak udangudangan (Crustacea) lainnya, Annelida dan detritus. Pada saat dewasa, udang sudah bersifat omnivora, karnivora, pemakan bangkai dengan pakan alami berupa daging hewan lunak atau Moluska (kerang, tiram, siput), Annelida, Polychaeta, udang-udangan, anak serangga (Chironomus) dan detritus.

\section{Indeks Keanekaragaman Plankton $\left(\mathbf{H}^{\prime}\right)$}

Dari hasil analisa diperoleh nilai indeks keanekaragaman plankton berkisar antara 0,97 2,26. Kisaran nilai tersebut menunjukkan keanekaragaman plankton tergolong rendah dan sedang. Nilai $\mathrm{H}^{\prime}$ dengan kategori rendah menunjukkan perairan tersebut mempunyai kestabilan komunitas yang rendah. Faktor-faktor yang mempengaruhi nilai indeks keanekaragaman menurut Pratiwi dan Widyastuti (2013) disebabkan oleh faktor fisika air, ketersediaan nutrisi, serta pemanfaatan nutrisi yang berbeda dari tiap individu, serta kemampuan dari masing-masing jenis plankton untuk beradaptasi/toleransi dengan perubahan lingkungan.

Tabel 3. Nilai Indeks Keanekaragaman Plankton $\left(\mathrm{H}^{\prime}\right)$ pada Tiap Stasiun

\begin{tabular}{lrrrrr}
\hline \multirow{2}{*}{ Keanekaragaman (H') } & $\mathbf{1}$ & $\mathbf{2}$ & $\mathbf{3}$ & $\mathbf{4}$ & $\mathbf{5}$ \\
\cline { 2 - 6 } & 2,26 & 0,97 & 1,22 & 1,48 & 1,79 \\
\hline
\end{tabular}

Menurut Odum (1993), tinggi rendahnya nilai indeks keanekaragaman dapat menjadi indikator kemampuan plankton beradaptasi. Nilai $\mathrm{H}^{\prime}$ yang rendah menunjukkan lemahnya kemampuan fitoplankton dalam memanfaatkan serta toleransi terhadap faktor lingkungan yang kurang mendukung, sehingga hanya terdapat genus tertentu yang melimpah. Sebaliknya, nilai keanekaragaman tinggi dapat disebabkan kemampuan spesies plankton beradaptasi dengan lingkungan sehingga produktivitas tinggi.

Nilai keanekaragaman $\left(\mathrm{H}^{\prime}\right)$ plankton tertinggi pada perairan muara Belawan ditemukan pada stasiun 1 sebesar 2,26 dimana lokasi ini merupakan kawasan alami yang minim aktivitas manusia dan memiliki ragam jenis mangrove, serta merupakan area pasang-surut terdekat dari muara sungai Belawan. Sedangkan stasiun 2 merupakan lokasi dengan nilai keanekaragaman $\left(\mathrm{H}^{\prime}\right)$ plankton terendah sebesar 0,97, dimana lokasi perairan ini terletak paling jauh dari muara sungai Belawan menjadikan lokasi ini paling lambat mengalami pergantian pasang-surut air yang membantu pergerakan plankton menuju area tersebut, Selain itu, kondisi vegetasi mangrove/tumbuhan yang rendah dan banyaknya buangan limbah anorganik dan organik hasil dari kegiatan masyarakat sekitar kemungkinan juga turut mempengaruhi kehadiran ragam plankton di badan air sekitar lokasi tersebut. Penelitian yang dilakukan oleh Simbolon et al. (2016); Karolina et al. (2014), menyimpulkan bahwa plankton sebagai salah satu 
perifiton pada perairan yang keberadaannya dapat dijadikan indikator perubahan kualitas biologi perairan sungai (bioindikator pencemaran air).

Dari analisa tersebut dapat disimpulkan bahwa kondisi perairan di muara Belawan kurang stabil dan mulai mengalami penurunan daya dukung lingkungan, kondisi pasang-surut dan kenaikan muka air laut pada waktu pasang ( $r o b)$ juga turut memberikan pengaruh bagi keragaman $\left(\mathrm{H}^{\prime}\right)$ plankton yang hakikatnya memerlukan arus sebagai alat bantu bagi persebarannya dalam suatu badan air. Fajrina et al. (2013); Arinardi (1997) bahwa kekuatan arus atau pergerakan massa air akibat pasang surut dapat mempengaruhi ketersediaan unsur nutrisi yang dimanfaatkan untuk menunjang metabolisme kehidupan fitoplankton serta siklus hidup maupun perioda reproduksinya.

\section{Korelasi Kelimpahan Plankton Terhadap Parameter Biologi (Populasi Udang Kelong (Penaeus indicus) dan Kerapatan Mangrove) Lingkungan \\ Dari hasil uji analisis korelasi pearson} antara kelimpahan plankton terhadap faktor biologi lingkungan (kerapatan mangrove dan populasi udang kelong $P$. indicus) menunjukkan korelasi positif/searah yang sangat kuat dengan nilai masing-masing sebesar 0.91 dan 0.94. Menurut Sarwono \& Budiono (2012), bahwa jika nilai korelasi berkisar 0.80 - 1.00 maka tingkat korelasi dikategorikan sangat kuat. Hasil ini menggambarkan hubungan searah yang berarti, semakin tinggi kerapatan mangrove dan kelimpahan plankton maka jumlah tangkapan udang kelong juga diprediksi akan semakin meningkat, dan begitu pula sebaliknya (Tabel 4).

Kehadiran plankton di badan perairan sangat berperan sebagai menyedia pakan alami bagi fase perkembangan udang penaeid seperti genus Penaeus di alam. Chong \& Sasekumar (1981), menyatakan pakan alami udang Penaeus merguiensis di perairan Angsa Bank-Klang Strait Malaysia sangat bervariasi bergantung pada habitatnya. Di daerah pembesaran/nursery ground, pascalarva udang $P$. merguiensis bersifat karnivora dan makanannya terdiri dari copepoda berukuran besar. Pada fase juvenile udang $P$. merguiensis selain mengkonsumsi detritus juga hewan-hewan kecil seperti foraminifera, kopepoda, larva bivalvia, dan larva branchyura. Pada saat juvenile dan beranjak dewasa udang $P$. merguiensis memakan krustase besar, acetes, dan mysid. Di daerah spawning ground, udang $P$. merguiensis menyukai makanan berupa detritus organik, krustase, polisaeta dan jenis-jenis moluska. Makanan alami yang dikonsumsi oleh udang putih akan digunakan untuk pertumbuhan, pergerakan, metabolisme dasar, reproduksi dan pergatian sel/kulit yang telah rusak.

Tabel 4. Hasil Korelasi Pearson Terhadap Parameter Biologi Lingkungan

\begin{tabular}{lcc}
\hline Parameter Biologi & Plankton (ind/L) & Korelasi \\
Udang (Ind $\left./ \mathrm{m}^{2}\right)$ & $\mathbf{0 . 9 4 2 *}$ & $(+)$ positif $($ searah $)$ \\
Mangrove (ind/Ha) & $0.910^{*}$ & $(+)$ positif (searah) \\
\hline Keterangan: *Korelasi signifikan pada tingkat kepercayaan $0.05(95 \%)$.
\end{tabular}

Menurut Kordi (2012), lingkungan ekosistem mangrove menjadi tempat yang cocok bagi biota akuatik untuk mencari makan (feeding ground), tempat memijah (spawning ground), dan pengasuhan anaknya (nursery ground). Dalam kaitannya dengan makanan, ekosistem mangrove menyediakan makanan bagi berbagai biota akuatik dalam bentuk material organik yang terbentuk dari jatuhan daun serta berbagai kotoran hewan darat yang kemudian diubah oleh mikroorganisme menjadi bioplankton yang sangat dibutuhkan biota laut.

Mumin (2004) mengemukakan, Beberapa udang penaeid di perairan Indonesia sangat bergantung pada mangrove, Martosubroto \& Naamin (1977); Robertson \& Duke (1987); Lee (2004); Baran (1999); Pauly \& Inges (1999); Blaber (2009) membuktikan bahwa terdapat hubungan nyata antara produksi udang dengan luas hutan mangrove. Sehingga dapat disimpulkan hutan mangrove memegang peranan penting dalam perikanan udang.

\section{KESIMPULAN}

Berdasarkan penelitian yang dilakukan, diperoleh kesimpulan bahwa:

1. Kelimpahan plankton tertinggi dijumpai pada stasiun 1 dan 3 yang didominasi oleh kelompok fitoplankton dengan genus Melosira, Gonatozygon, Skeletonema, Asterionellopsis, Ceratium, Thalassionema, Odontella, Nitzchia, dan Coscinodiscus. Kelompok zooplankton dengan genus Brachionus dan Cyclops. Sedangkan Kelimpahan plankton terendah dijumpai pada stasiun 2 dan 5 .

2. Nilai indeks keanekaragaman $\left(\mathrm{H}^{\prime}\right)$ plankton tertinggi di perairan muara Belawan ditemukan pada stasiun 1 sebesar 2,26 yang merupakan kawasan alami dengan minim aktivitas manusia dan memiliki ragam jenis mangrove, serta merupakan area pasangsurut yang baik. Sedangkan stasiun 2 yang terletak paling jauh dari muara sungai Belawan menjadikan lokasi ini paling lambat mengalami pergantian pasang-surut air dengan nilai indeks keanekaragaman $\left(\mathrm{H}^{\prime}\right)$ plankton terendah sebesar 0,97. 
3. Hasil uji analisis korelasi pearson antara kelimpahan plankton terhadap faktor biologi lingkungan (kerapatan mangrove dan populasi udang kelong $P$. indicus) menunjukkan korelasi positif/searah yang sangat kuat dengan nilai masing-masing sebesar 0.91 dan 0.94 .

\section{DAFTAR PUSTAKA}

Angsupanich, S., Chiayvareesajja S., Chandumpai A. 1999. Stomach Content of The Banana Prawns Penaeus indicus and $P$. merguiensis) in Tammalang Bay, Southern Thailand. Asian Fishery Science. 12 (257-265).

APHA (American and Public Health Assosiation). 1998. Standar Method for Examination of Water and Wastewater. 20th ed. New York: APHA.

Arinardi, O.H., Trimaningsih., Sudirjo, 1997. Kisaran Kelimpahan dan Komposisi Plankton Predominan Di Kawasan Timur Indonesia. Pusat Penelitian dan Pengembangan Oseanografi-LIPI. Jakarta. $139 \mathrm{hlm}$.

Baran, E. 1999. A Review of Quantified Relationships Between Mangroves and Coastal Resources. Phuket Marine Biological Canter Research Bulletin no.62.

Blaber, S.J.M. 2009. Ecological Among Tropical Coastal Ecosystems. Connectivity Australia: Springer Science Business Media B.V.

Chong, V.C., Sasekumar A. 1981. Food and feeding habits of the white prawn Penaeus merguiensis in the Angsd Bank-Klang Strait waters (Straits of Malacca). Marine ecology - progress series 5.

Davis, C.C. 1955. The Marine and Freshwater Plankton. Michigan State University Press. United States of America.

Dinas Kehutanan Provinsi Sumatera Utara. 2011. Review Peta Sebaran Potensi Mangrove. Balai Pengelolaan Hutan Mangrove. Medan.

Edhy, W.A., Azhary, K., Pribadi, J., M. Chaerudin K. 2010. Budidaya Udang Putih: Littopenaeus vannamei. Boone, 1931. CV. Mulia Indah. Jakarta.

Faiqoh, E. 2009. Kelimpahan dan Distribusi Fitoplankton Serta Hubungannya dengan Kelimpahan dan Distribusi Zooplankton Bulan Januari- Maret 2009 di Teluk Hurun, Lampung selatan. Publikasi Tesis. Pascasarjana Universitas Indonesia. $109 \mathrm{hlm}$

Fajrina, H., Endrawati, H., Zainuri, M. 2013. Struktur komunitas fitoplankton di perairan morosari Kecamatan sayung kabupaten demak. Journal of Marine Research. Volume 2 (1): 71-79

Fast, A. W., Lester, L. J. 1992. Pond Monitoring and Management Marine Shrimp Culture Principle and Practise. Netherlands: Elsevier Science Publisher Amsterdam.

Karolina, M., Mulya M.B., Leidonald R. 2014. Kualitas Air Dan Hubungannya Dengan Keberadaan Plankton Di Sungai Sunggal Provinsi Sumatera Utara. Jurnal Aquacoastmarine. Vol 2 (3): 123-130
Kordi, M.G.H. 2012. Ekosistem Mangrove: Potensi, Fungsi dan Pengelolaan. Cetakan Pertama. Penerbit Rineka Cipta. Jakarta

Lee, S.Y. 2004. Relationship Between Mangrove Abundance and Tropical Prawn Production: A Re-evaluation. Marine Biology Journal No.145.

Liao, I.C., Murai T. 1986. Effect of Disolved Oxygen Consumption of The Grass Shrimp, Penaeus monodon. Machlean, LB., Dizon and LV. Hossilos (Eds). The First Asian Fisheries Forum.Philippines : Asian Fisheries Society.

Martosubroto, P., Naamin N. 1977. Hubungan antara hutan mangrove dan produksi udang komersial di Indonesia. Jurnal Kelautan volume 8.

Melay, S., Rahalus, K.D. 2014. Struktur komunitas zooplankton Pada ekosistem mangrove di Ohoi/desa Kolser Maluku Tenggara. Jurnal Biopendix, Volume 1, Nomor 1. hlm. 101-110

Mumin, M. 2004. Analisis Kondisi Ekosistem Mangrove Dan Pengaruhnya Terhadap Komposisi Ikan dan Udang Di Teluk Bula, Pulau Seram, Kabupaten Maluku Tengah, Provinsi Maluku. Tesis Pascasarjana IPB. Bogor.

Odum, E.P. 1993. Dasar-dasar Ekologi. Edisi Ketiga Penerjemah Ir. Tjahjono Samingan, MSc. Gajah Mada University Press. $630 \mathrm{hlm}$.

Pauly, D., Ingles J. 1999. The Relationship Between Shrimp Yields and Intertidal vegetation (mangrove) Areas: A Reassesment. Ecosistemas de Manglar en America Tropical Journal. 380 p

Pratiwi, R., Widyastuti, E., 2013. Pola sebaran dan zonasi krustasea di hutan bakau perairan Teluk Lampung. Zoo Indonesia. Vol 22(1):11-21

Robertson, A.I., Duke N.C. $1987 . \quad$ Mangroves as Nursery Sites: Comparisons of The Abundance and Species Composition of Fish and Crustaceans in Mangroves and Other Nearshore Habitats in Tropical Australia. Springer Journal: Marine Biology Vol. 96 (2) 247: 193 - 205.

Sarwono, J., Budiono H. 2012. Statistik Terapan: Aplikasi Untuk Riset Skripsi, Tesis, dan Disertasi menggunakan SPSS, AMOS, dan Excel. Elex Media Komutindo, Jakarta.

Simbolon, C., Mulya MB., Desrita. 2016. Keanekaragaman Perifiton Di Sungai Belawan Kecamatan Pancur Batu Kabupaten Deli Serdang Provinsi Sumatera Utara. Jurnal Aquacoastmarine. Vol 4 (1): 1-10

Sumeru, S.U., Anna, S. 1992. Pakan Udang Windu (Penaeus monodon). Kanisius. Yogyakarta.

Supriadi, I.H. 2001. Dinamika Estuaria Tropik. Jurnal Oseana. Vol 26 (4). 